Case Report

\title{
Hearing Loss in Treacher-Collins Syndrome
}

\author{
Fezzan Athama Fuadi, Wijana \\ Department of Otorhinolaryngology Head and Neck Surgery \\ Faculty of Medicine, Universitas Padjadjaran / Dr. Hasan Sadikin General Hospital, \\ Bandung
}

\begin{abstract}
Background: Treacher Collins Syndrome (TCS) is a craniofacial disorder that has a dominant autosomal disorder in facial development, found 1 in every 50.000 births. The most often manifestations could be mandibulofacial disorder, microtia, atresia of the ear canal, and hearing loss. This syndrome is also accompanied by bone malformations of the ossicular chain in the middle ear, which can lead to conductive hearing loss up to $50 \%$ of cases, besides sensory neural hearing loss. Purpose: To report one case of Treacher Collins syndrome who came to the Audiology-Vestibular Clinic, Dr. Hasan Sadikin General Hospital Bandung. Case report: The patient came with symptoms of micrognathia and microtia with bilateral hearing loss. The right ear is smaller than the left ear, and compliant with 3rd grade microtia. He had undergone reconstruction ear surgery of the right ear, and had an improvement in audiological examination after the second stage of reconstruction. There was TCOF 1 (Treacle Ribosome Biogenesis Factor 1) gene mutation involved in this case. Clinical question: What is the best management for TCS with micrognathia, microtia and severe bilateral hearing impairments? Review method: Literature search was performed with keywords Treacher Collins Syndrome AND microtia AND hearing loss. Result: The search obtained 263 literatures published in the last 10 years, and found 12 articles relevant with the topics. Conclusion: TCS is a rare inherited disorder, but the diagnosis could be easily established. Early intervention with hearing rehabilitation, audio-verbal rehabilitation, and reconstruction ear surgery should be carried out for a better quality of life.
\end{abstract}

Keywords: Treacher Collins syndrome, micrognathia, microtia, hearing loss

\section{ABSTRAK}

Latar belakang: Sindroma Treacher Collins adalah kelainan kongenital auotosom dominan pada kepala dan wajah, yang ditemukan pada 1 dari 500,000 bayi lahir. Manifestasi yang paling sering didapati adalah kelainan mandibulofasial, mikrotia, atresia liang telinga, dan gangguan pendengaran. Pada sindroma ini terjadi malformasi rangkaian tulang-tulang pendengaran di telinga tengah, yang mengakibatkan tuli konduktif pada 50\% kasus, dan dapat juga disertai tuli sensorineural. Tujuan: Melaporkan satu kasus sindroma Treacher Collins yang datang ke poliklinik Audiology-Vestibular, Rumah Sakit Umum Dr. Hasan Sadikin, Bandung. Laporan Kasus: Keluhan utama pasien adalah mikrognatia dan mikrotia disertai gangguan pendengaran kedua telinga. Bentuk telinga kanan lebih kecil daripada telinga kiri, yang sesuai dengan mikrotia derajat 3. Pasien menjalani bedah rekonstruksi telinga kanan, dan memperoleh perbaikan hasil pemeriksaan audiogram pasca tahap kedua bedah rekonstruksi. Pada kasus ini didapati ada mutasi genetik TCOF 1 (Treacle Ribosome Biogenesis Factor 1). Pertanyaan klinis: Bagaimana penatalaksanaan terbaik untuk kasus STC dengan mikrognatia, mikrotia dan gangguan pendengaran berat kedua telinga. Telaah literatur: Penelusuran literatur melalui Google Scholar dilakukan dengan kata kunci Treacher Collins Syndrome DAN microtia DAN hearing loss. Hasil: Didapatkan 263 literatur mengenai STC yang terbit dalam 10 tahun terakhir, dan 12 literatur yang sesuai dengan topik. Kesimpulan: Sindroma Treacher Collins adalah kelainan bawaan langka yang merupakan penyakit keturunan, namun diagnosisnya tidak sulit ditegakkan. Perlu dilakukan intervensi dini berupa rehabilitasi pendengaran, rehabilitasi wicara, dan bedah rekonstruksi telinga untuk memberikan kualitas hidup yang baik bagi penderita. 
Kata kunci: sindroma Treacher Collins, mikrognatia, mikrotia, gangguan pendengaran

Correspondence address: Fuadi FA, Department of Oto Rhino Laryngology-Head and Neck Surgery, Faculty of Medicine, Universitas Padjadjaran / Dr. Hasan Sadikin General Hospital, Bandung. Email:fezzanfuadi@gmail.com.

\section{INTRODUCTION}

Treacher Collins syndrome (TCS) is a rare congenital disorders, which is caused by autosomal mutation of the gene, and disrupts the development of bones and body tissue on the face that resulted in craniofacial abnormalities. ${ }^{1,2}$ Other names for this disorder are mandibulofacial dystostosis, Treacher Collins-Franceschetti syndrome (TCFS), Franceschetti Zwahlen-Klein syndrome, mandibulofacial dysostosis (MFD) and zygoauromandibular dysplasia..,4 This syndrome is characterized by hearing loss, downward slanting position of the eyes, notched lower lids, and ear deformity. ${ }^{4}$ The hearing function can also be disrupted in the form of conductive hearing loss caused by malformations of the auditory bone and abnormalities in the outer ear, which was occurring in approximately $30 \%$ of cases. In some cases, there were also sensorineural hearing loss and vestibular disorders. ${ }^{1-3}$

This syndrome was first described by Thompson in 1846, but became better known after a leading British ophthalmologist named Edward Treacher Collins, examined 2 cases in 1900, so it was termed TreacherCollins Syndrome. A Swiss ophthalmologist Franceschetti and a geneticist Klein, also named the syndrome "mandibulofacial dystostosis", after conducting research and publishing an article in 1949. .-5 $^{-5}$

TCS arises 1 in of every 50,000 births, and about $60 \%$ cases were autosomal. This syndrome occurs because of an abnormality of a TCOF 1 (Treacle Ribosome Biogenesis Factor 1) gene (locus 5q32) which is responsible for encoding the Treacle nucleolus phosphoprotein, which is directly involved in the development of the two branchial branches. At this stage, these genes improve mutations and change their function in craniofacial development. Mutations in this gene can be inherited in about $40 \%$ cases. Individuals who have a TCOF1 mutation have a $50 \%$ chance of transmitting it to their children in the future. In clinical study, although the causative mutations in a subset of patients had not been identified, TCS was thought to be genetically homogeneous because all the multigenerational families analyzed to date exhibit linkage to the human chromosome $5 q 32$ locus. Intriguingly, however, $60 \%$ of the cases did not appear to have a previous family history and were thought to arise as the result of mutation. ${ }^{1,3,7}$

Facial disorders in TCS that often occured include hypoplasia of the facial bones, in particular the zygomatic complex $(81 \%)$, hypoplasia of the mandible $(78 \%)$, high arched palate, and cleft palate (28\%). In severe cases, the zygomatic arch might be completely absent. Facial bone hypoplasia might result in dental malocclusion, with anterior open bites. The teeth might be widely spaced, malpositioned or the number reduced. Eye abnormalities included down slanting of the palpebral fissure (89\%), with coloboma in the lower eyelid (69\%), and paucity of lid lashes medial to the defect $(69 \%))^{1-5}$

Hearing disorders that occured vary greatly, depending on the severity of ear deformity, it range from mild to severe. ${ }^{1}$ Between $30-50 \%$ of children affected had severe bilateral conductive hearing loss, as a result of external auditory canal stenosis or middle ear malformation. Radiographic analysis of the middle ear of TCS patients 
reveals irregular or absence of auditory ossicles, such as the absence of malleus and incus, or fusion between rudiments of the malleus and incus, partial absence of stapes and oval windows, or even complete absence of the middle ear cavity and epitympanic space. The malformation often affected the patient's hearing, so that hearing rehabilitation should be attempted as early as possible, to ensure adequate language development and learning. ${ }^{3-5}$

Treacher-Collins syndrome is a congenital disorder that can affect the development of speech and language. ${ }^{6}$ The disorder is not widely known and the incidence is very low. The purpose of presenting this case was to share one rare case of TCS in order to increase the knowledge of colleagues regarding TCS diagnosis and its management.

\section{CASE REPORT}

A 32 year old man came with micrognathia and bilateral tiny ear, coexisted with hearing disorder since childhood. The right ear was smaller than the left ear and accompanied by atresia of the ear canal. However, the patient could communicate effectively and was able to speak although not fluently. The patient was the first child of two siblings, and his younger sister had no facial or hearing abnormalities.

The patient's mother did not have a history of any particular diseases, but she often consumed traditional herbal medicine during pregnancy and often experienced work-related stress. The patient was normally born at 8 months gestation, with body weight of 2800 grams, in a hospital assisted by an obstetrician-gynaecologist. He did not directly cry after birth. Because of premature born, he was hospitalized in Neonatal Intensive Care Unit for 1 week, and assisted by a ventilator. The patient also had icterus after birth, and was treated at the NICU with blue light therapy. The patient did not get breast milk as a baby. There was no history of other diseases. Motoric development was normal in accordance to his age. The speech development manifested as babbling ability at 12 months of age. Up till now the patient could not speak fluently and tended to be quiet. The patient did not attend formal school. There were no facial or hearing abnormalities in his parents. There was no history of TCS in his family, and history of birth defect was occurred in the son of his mother's older sister as a cleft lip.

On physical examination, there was micrognathia. The left ear had no antihelix and the tragus enlarged. The right ear was undeveloped, just peanut-like lobule. Nose examination was within normal limits. There were crowded front teeth in the lower jaw. There were no cranial nerve palsy, nor eyes abnormalities, and nor palpable lymph nodes in the neck.
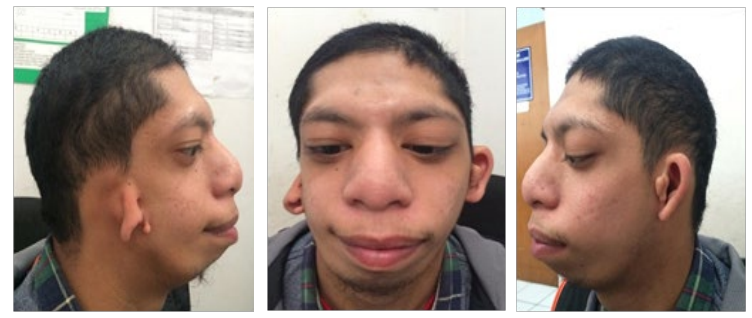

Figure 1. Clinical pictures

In pure tone audiometry examination, there was profound hearing loss in the right ear with hearing threshold of more than 110 $\mathrm{dB}$, and moderate conductive hearing loss in the left ear with hearing threshold of 56.25 $\mathrm{dB}$.

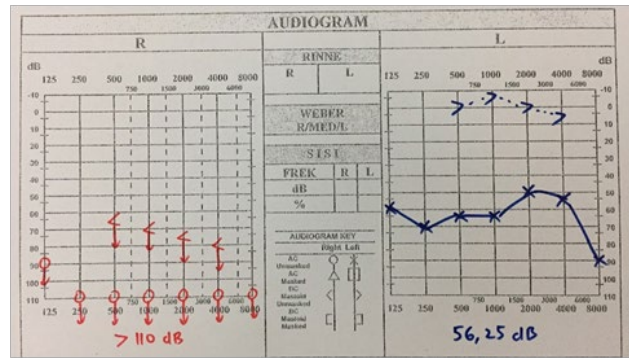

Figure 2. Before operation 
On temporal CT scan examination, the right auricle looked small with agenesis of the right external and internal acoustic canal, supporting the description of $3^{\text {rd }}$ grade microtia in the right ear. The left auricle looked small with narrowing of the external acoustic canal, and normal internal acoustic canal, in accordance to $1^{\text {st }}$ grade microtia in the left ear.

The patient was scheduled for reconstruction surgery of the right ear. After the first stage of reconstruction, an audiometric evaluation was performed and obtained a hearing threshold of $95 \mathrm{~dB}$.

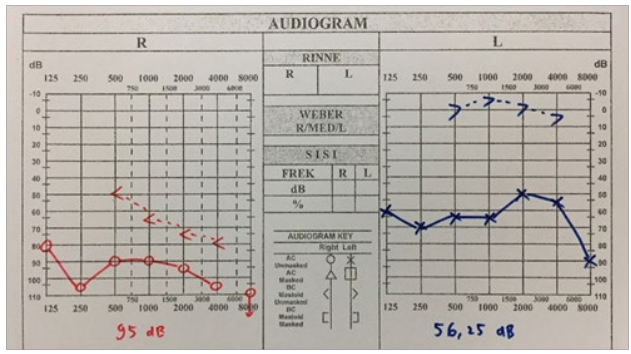

Figure 3. After 1st operation

Subsequently the patient underwent second stage of ear reconstruction surgery. The postoperative audiometric evaluation showed that the hearing threshold increased to $75 \mathrm{~dB}$.

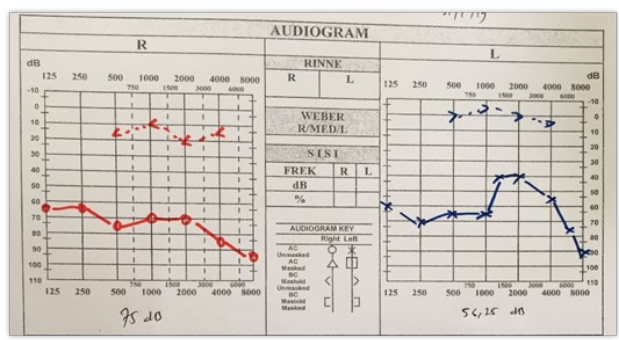

Figure 4. After 2nd operation

Afterwards, the patient was advised to wear hearing aids and to attend audio-verbal rehabilitation.

The diagnosis of TCS in this patient was established by the features of micrognathia and bilateral ears deformity, with profound hearing loss in the right ear and conductive hearing loss in the left ear.

\section{CLINICAL QUESTION}

What is the best management for a case of TCS with micrognathia, microtia and severebilateral hearing impairments?

\section{REVIEW METHOD}

Literature search was performed with keywords 'Treacher Collins Syndrome' AND 'microtia' AND 'hearing loss' was conducted through Cochrane, Pubmed and Google Scholar.

\section{RESULT}

From the search obtained 263 literatures published in the last 10 years, and found 12 articles relevant with the topics.

\section{DISCUSSION}

Treacher-Collins syndrome (TCS) or mandibulofacial dystostosis has a variety of aspects in abnormalities that occur in patients, both clinically and audiologically. TCS requires multidisciplinary approach especially in hearing rehabilitation and cosmetics to improve the patient's quality of life.

The onset of TCS abnormalities occurs very early during human embryonic development, within the first 4-8 weeks gestation, and diagnosing TCS prenatally is very important. It could be achieved by using two dimensional ultrasonography, or three dimensional ultrasonography if available. ${ }^{12}$ Conte et $\mathrm{al}^{7}$ and Schlump et al. ${ }^{11}$ reported genetical reseach on TCS cases.

Trainor et al. ${ }^{5}$ found hypoplasia of the facial bone, particularly of the mandible $(78 \%)$ and zygomatic complex (81\%) as the 
most common feature in TCS. Hypoplasia of the facial bone might result in dental malocclusion with anterior open bite, and the teeth might be widely spaced, malpositioned, or reduced in number. ${ }^{6}$ These features were closely related with micrognathia. Rosa et al. ${ }^{3}$ reported external ear abnormalities in TCS patients, the highest was microtia ( $95 \%$ of cases), canal atresia ( $78 \%$ of cases), and canal stenosis $(22 \%$ of cases $)$. These were also accompanied by structural abnormalities in the middle ear, which affecting the patients' hearing process.

Hearing loss in TCS can be conductive or sensorineural, and the degree depends on the abnormalities of the otological structures. About $50 \%$ of individuals with TCS, had conductive hearing disturbance, unilateral or bilateral, which usually in moderate to profound degree. ${ }^{8}$

Early screening of hearing loss is mandatory in dealing with this syndrome, especially when the patient was born with craniofacial abnormalities. Hearing rehabilitation should be implemented early, because it will have an impact on the development of speech language of the patients. On the other hand, the reconstruction of the ears of patients experienced with microtia is also very important to do early, because it is not only about improving the hearing function, but also relates to the cosmetic aspect, so that patients will become more confident.

We reported an adult male patient with TCS who came to the Audiology-Vestibular Clinic at Dr. Hasan Sadikin Hospital Bandung. The patient had micrognathia that also accompanied by bilateral microtia and hearing loss that had interfered his physical and personality development.

There was an abnormality in the size and shape of the ears, which the right ear was smaller than the left ear. According to the criteria from Aguilar and Jahrsdoerfer, the right ear was the in the $3^{\text {rd }}$ grade of microtia, and required a two-stage or more reconstruction ear surgery procedure. The left ear was in the $1^{\text {st }}$ grade of microtia, and did not need any reconstruction. ${ }^{8,9}$

In this case, the possibility of TCS was due to the TCOF 1 gene mutation that has an autosomal dominant. According to Trainor et al. ${ }^{5} 60 \%$ of the case emerged spontaneously.

Audiometric examination of this patient was performed on his first visit (Picture 2), after the first stage of reconstruction ear surgery (Picture 3), and after the second stage of reconstruction ear surgery (Picture 4). The reconstruction surgery was only performed on his left ear. The results showed an improvement in the hearing threshold about 15 $\mathrm{dB}$ after the first stage of reconstruction, and $20 \mathrm{~dB}$ after the second stage of reconstruction. The type of the hearing disturbance also changed from profound hearing loss to severe conductive hearing loss, and finally became moderate conductive hearing loss. The audiometric examination result of the left ear was moderate conductive hearing loss, with hearing threshold of $56.25 \mathrm{~dB}$. The left ear was not being operated.

Treacher-Collins syndrome has a distinctive clinical picture, so the initial diagnosis can be easily enforced. In this case report, a typical abnormality found of this syndrome was micrognathia, abnormal ear structures, and the presence of hearing loss which resulted in delayed speech and disruption of the patient's personality. The patient underwent right ear reconstruction surgery in two stages, and there was an improvement on his hearing function Afterwards he was fitted with hearing aid.

It is important for parents to know about congenital abnormalities that occur in their babies, hence it needs early evaluation, including the hearing function. Early diagnosis is important, because then the doctor could decide about intervention needed such as 
reconstruction procedure for improving the hearing function, cosmetic reconstruction, and also audiological intervention such as providing hearing aids so the child's hearing and verbal language could be well developed, and the patient could achieve a good quality of life.

\section{REFERENCE}

1. Tewfik TL. Pediatric Otolaryngology. Johnson JT, Rosen CA, Newlands S, Amin M, Branstetter B, Casselbrant M, et al. Bailey's Head \& Neck Surgery Otolaryngology . 5th ed. USA: Lippincott Williams \& Wilkins; 2014: 1622-33.

2. Strauss $M$, Navrozov $M$, Saggese $C H$, McKeon M, Nickerson A. K.J. Lee Essential Otolaryngology Head \& Neck Surgery. 11th ed. USA: The McGraw-Hill Companies, inc; 2015: 825-30.

3. Rosa F, Coutinho MB, Ferreira JP, Sousa CA. Ear malformations, hearing loss and hearing rehabilitation in children with Treacher Collins Syndrome. Acta Otorhinolaringol Esp. 2016; 67(3): 142-7.

4. Shete P, Tupkari JV, Benjamin T, Singh A. Treacher Collins Syndrome. J Oral Maxillofac Pathol. 2011; 15(3): 348-51.

5. Trainor PA, Dixon J, Dixon MJ. Treacher Collins Syndrome: etiology, pathogenesis, and prevention. Eur J of Hum Genet. 2009; 17(3): 275-83.

6. Massi G, Franca DR, Santos RS, Ribas A, Fonseca VD, Guarinello AC, et al. Speech language pathology findings in a Treacher Collins Syndrome patient. Int Tinnitus J, Brazil. 2016; 20(1): 31-5.

7. Conte C, D'Apice MR, Rinaldi F, Gambardella S, Sangiuolo F, Novelli G. Novel mutations of TCOF1 gene in European patients with Treacher Collins syndrome. BMC Med Genet; 2011; 12: 125-9.

8. Cummings CW, Fredrickson JM, Harker LA, Krause CJ, Schuller DE, et al. Sensorineural hearing loss in children. Otolaryngology Head \& Neck Surgery. 6th ed. USA: Mosby Year Book; 2015. p. 3085-6.
9. Thorne CHM, ed. Otoplasty and Ear Reconstruction. Grabb and Smith's Plastic Surgery. 7th Ed. USA: Lippincott Williams \& Wilkins; 2013: 842-9.

10. Hylton JB, Leon-Salazar V, Anderson GC, De Felippe NLO. Multidiciplinary treatment approach in Treacher Collins Syndrome. J Dent Child; 2012; 79: 15-21.

11. Schlump JU, Stein A, Hehr U, Karen $\mathrm{T}$, Moller-Hartmann C, Elcioglu NH, et al. Treacher Collins syndrome: Clinical implications for the paediatrician - a new mutation in a severely affected newborn and comparison with three further patients with the same mutation, and review of literature. Eur J Paediatr. 2012; 171: 1611-8.

12. Oliveira JP, Lodovichi F, Gomes MB, Custodio EM, Denadai R, Raposo-Amaral CA, et al. Patient-Reported Quality of Life in the Highest Functioning Patients With Treacher Collins Syndrome. J Craniofac Surg. 2018; 29(6): 1430-3. 